\title{
Continuous cover forestry: possible implications for surface water acidification in the UK uplands
}

\author{
B. Reynolds \\ Centre for Ecology and Hydrology Bangor, University of Wales Bangor, Deiniol Road, Bangor, Gwynedd LL57 2UP, Wales, UK
}

Email: br@ceh.ac.uk

\begin{abstract}
The effects of widespread conifer afforestation on the acidity of lakes and streams in the acid sensitive uplands of the UK has been researched extensively and has contributed to the development and implementation of national forest management guidelines (e.g. Forest and Water Guidelines; Forestry Commission, 1993). However, a recent policy document (Woodlands for Wales; National Assembly for Wales, 2000) has proposed a major shift in the management of $50 \%$ of the Forestry Commission estate in Wales from the current system of patch clearfelling to Continuous Cover Forestry (CCF). This scale of change is without precedent in the UK; no studies in the UK forest environment have examined the likely environmental impacts of CCF. However, the wealth of environmental data from studies of UK forests managed by patch clearfelling enables an assessment of the impact of a change to CCF on three issues of particular relevance to surface water acidification in the uplands; forest harvesting, soil base cation depletion and atmospheric pollutant deposition. Whilst there is uncertainty as to how evenaged stands will be transformed to CCF in the UK, guiding principles for CCF on acidic and acid sensitive sites should focus on those aspects of management which minimise nitrate leaching, encourage base cation retention within the soil-plant system and enhance base cation inputs from external (atmospheric) and internal sources (weathering). CCF may provide opportunities to achieve this by reducing the scale of clearfelling, increasing species diversity, changing the structure of plantation forests and maintaining uninterrupted woodland cover.
\end{abstract}

Keywords: acidification, forestry, continuous cover forestry, clearfelling

\section{Introduction}

The main silvicultural system employed in approximately $90 \%$ of managed conifer forests in Britain is patch clearfelling followed by re-planting or, occasionally, natural regeneration. Generally the mean size of felled patches, or coupes, ranges between 5 and 10 hectares, although there is considerable regional variation (Mason et al., 1999). For example, in Welsh forests managed by Forest Enterprise, over half (57\%) of felling coupes are less than 10 ha and $81 \%$ are less than 20 ha in area; less than $3 \%$ exceed 50 ha in area. However, there is currently increasing pressure for the sustainable development of multi-purpose forestry in which environmental, recreational, aesthetic and other considerations are as important as timber production (Forestry Commission, 1998). One option for increasing the species and structural diversity required to achieve this multi-purpose goal is to move away from patch clearfelling towards a system of continuous cover forestry (Mason et al., 1999; Mason and Kerr, 2001). Many terms have been used to define continuous cover forestry (CCF). The definition proposed by Mason et al. (1999), the use of 'silvicultural systems whereby the forest canopy is maintained at one or more levels without clearfelling' has been adopted in this paper as it encompasses the distinctive features of CCF. Thus, CCF represents a significant change in commercial forest management practice. The recent policy document 'Woodlands for Wales' proposes that at least 50\% of the Forestry Commission estate in Wales be converted to CCF over the next 20 years (National Assembly for Wales, 2000).

There is still debate within the forest industry as to how CCF will be implemented in practice because of the lack of experience of $\mathrm{CCF}$ in British managed spruce forests. Furthermore, the different species and site conditions found 
in the UK imply that management systems developed in other parts of the world will have to be adapted through experimental trials and research. Current thinking (Mason et al., 1999; Mason and Kerr, 2001) is that the main effects of CCF will be to: (i) maintain continuous, uninterrupted forest cover, thereby reducing the impact of clearfelling and its associated changes in landscape, habitat, leaching and erosion losses, (ii) increase the range of tree species present, (iii) alter the age structure of forests away from largely evenaged to mixed age stands and iv) encourage the development of natural regeneration and understorey vegetation.

Notwithstanding some British examples of CCF such as the Glentress trials in Scotland (Anderson, 1960) and the 'Bradford' trials (Timmis, 1994), the effects on the acidity of surface waters will have to be inferred from the results of studies on existing forest plantations and woodlands. Whilst these can provide valuable information and could, in the future, form a basis for the development of predictive models, the limitations must also be recognised. Most relevant studies have been undertaken to assess the environmental impacts of a particular forestry practice or to assess sustainability issues. Hence, management options for implementing CCF may arise for which there are no analogue studies in the UK.

\section{Short-term acidification impact of clearfelling}

One of the clearest statements in regard to CCF is that it "commits the forest manager to using an alternative silvicultural system to patch clearfelling" (Mason et al., 1999). Given the clarity of this statement, it seems logical to consider this stage of the forest cycle first. Since the mid1980s, numerous studies of the effects of clearfelling on stream water chemistry and site nutrient status have encompassed scales from soil plot (Stevens and Hornung, 1988) to regional survey (Neal et al., 1998a); investigations of the effects of soil type and harvest intensity (stem-only vs. whole-tree harvesting (Stevens and Hornung, 1990)) have been included. Following an exhaustive study for the Environment Agency (Neal and Reynolds, 1998), practical management prescriptions to minimise the acidification impacts of clearfelling in acid sensitive areas have been incorporated into the most recent edition of the Forests and Water Guidelines (Forestry Commission,

Over two to three years following clearfelling, stream acidification may increase due to the accelerated leaching of nitrate from felled sites caused by the disruption of the nutrient cycle and enhanced rates of soil organic matter mineralisation and nitrification. The duration and intensity of this effect is determined by the proportion of the catchment felled, the method of harvesting, the rapidity of re-vegetation and soil type. Indeed, it is often very hard to discern any acidification effect at all where less than $20 \%$ of the catchment is felled within a three year period (i.e. small patch clearfells), or where there is progressive, incremental felling of a catchment over an extended period of 10 or more years (Neal et al., 2004). Large effects are observed only in small catchments where all the trees are harvested (e.g. Fig. 1). Leaching losses of nitrate and other nutrients can be reduced by whole-tree harvesting which allows rapid re-vegetation of the site compared to conventional stem-only harvested plots which re-vegetate relatively slowly due to the felling debris (Fahey et al., 1991). In Beddgelert forest, leaching losses of nitrogen from beneath the rooting zone of conventionally felled plots were $208 \mathrm{~kg} \mathrm{~N} \mathrm{ha}^{-1}$ over four years compared with $148 \mathrm{~kg} \mathrm{~N} \mathrm{ha}^{-1}$ from whole-tree harvested plots (Stevens and Reynolds, 1993). However, the beneficial effects of whole-tree harvesting in reducing leaching losses of both nitrogen and base cations can be more than outweighed by the longerterm acidification because of the greater removal of base cations in harvested products (Reynolds and Stevens, 1998). More nitrate leaching is generally observed in minicatchments draining relatively aerobic soils such as podzols compared to anaerobic gley soils (Neal et al., 1998b).

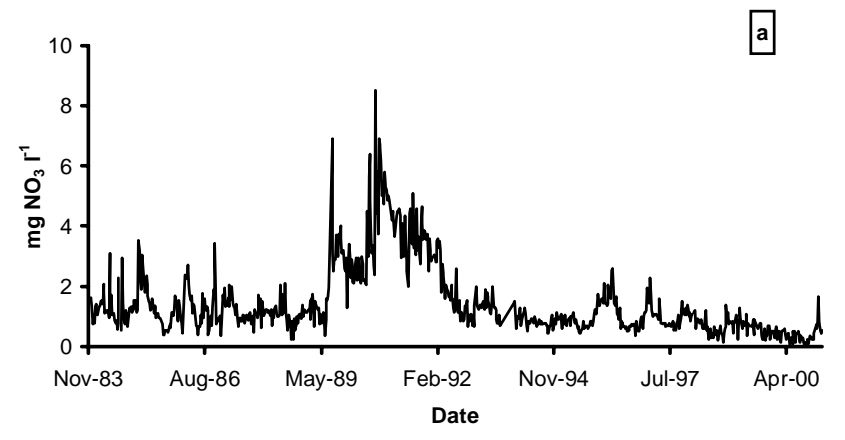

b

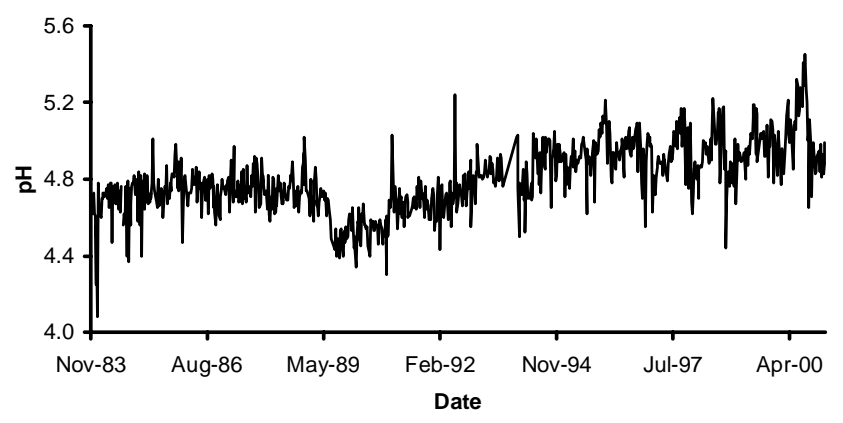

Fig. 1. Stream water nitrate concentration (a) and stream $p H(b)$ following clearfelling of the 14 ha South2Hore catchment at Plynlimon in the autumn of 1988 (Stevens et al., 2001). 
The short-term, net acidifying effect of clearfelling on the stream is a balance between the increase in nitrate and base cation leaching from the soil, the reduction in acid anion and base cation inputs due to removal of the forest canopy, dilution by increased runoff because of reduced evaporation losses and possibly increased weathering of soil minerals (Neal and Reynolds, 1998). After 10 years or so, re-growth of the forest may reduce stream water nitrate concentrations to levels below those observed in streams draining mature forest and even semi-natural moorland vegetation (Stevens et al., 2001) as the new forest takes up the available nitrogen.

The overall conclusion from the Environment Agency study was that, with the exception of some small (5-10 ha) catchments with $100 \%$ clear fell, the net acidification effect of felling was hard to distinguish from background temporal variations in water quality from other causes (Neal and Reynolds, 1998). Even where the entire catchment was felled, the ANC response was generally less than $30 \mu \mathrm{Eq} 1^{-1}$. Hence, the short-term effects of clearfelling on water quality can be minimised by close adherence to published guidelines and good practice manuals (e.g. Forestry Commission, 1993; Nisbet et al., 1997) with particular emphasis on:

(1) Phased felling operations within a catchment so as to dilute the effects of runoff from (a) the remaining standing forest and (b) areas clearfelled two or more years earlier which will contribute less acidic water than both the standing crop and the recently felled area.

(2) Encouraging early re-vegetation of the site to minimise nitrate leaching losses and the potential acidification.

In terms of a change in management from patch clearfelling to $\mathrm{CCF}$, any silvicultural practice that minimises nitrate leaching losses at felling is likely to be beneficial in reducing short-term acidification effects. One of the main benefits of CCF may arise from maintaining vegetation cover through controlled thinning so that nitrogen and base cations continue to be taken up within the soil-plant system. The development of a mixed age structure where patches of younger forest can take up nitrate released from adjacent felled areas will also be beneficial.

\section{Long-term acidification due to forest growth and soil base cation depletion}

The longer term acidification impact of patch clearfelling followed by re-planting is linked to the overall balance in the soil between (i) the export of base cations in harvest products, (ii) accelerated leaching losses of base cations at felling and (iii) the supply of base cations from atmospheric inputs and weathering. An analysis of calcium cycling within a chrono-sequence of Sitka spruce stands growing on basepoor soils typical of the uplands (Reynolds and Stevens, 1998) coupled with dynamic water quality modelling (Evans et al, 2001; Forestry Commission / Environment Agency, 2001) suggests that the soil calcium budget for plantation Sitka spruce in acid sensitive upland areas is finely balanced within the errors of the measurements. Estimates of weathering rates and atmospheric inputs are particularly problematic. Compared to stem-only harvesting, whole-tree harvesting causes more severe soil base cation depletion so this technique is not recommended for acid sensitive sites (Nisbet et al., 1997). Whether net removal of base cations in harvest products will change as a result of a shift to CCF will depend on the management of timber production within $\mathrm{CCF}$ as well as on the choice of species with subsequent effects on the biogeochemical cycling of base cations.

Maintaining long-term soil base cation reserves in production forests is complex and requires further research. Prediction of the likely effects of CCF on the biogeochemical cycling and balance of base cations is difficult but this is an important consideration for the long-term sustainability of upland forestry on base-poor soils. Part of the complexity lies in distinguishing the effects of acid deposition from those of forestry per se on soil and, hence, on stream water acidification. Many studies of soil acidification by forests or individual trees (see e.g. Hornung, 1985) show that the direction and magnitude of the changes in soil chemistry depend on the initial chemical status of the soil and the tree species. Generally, fast growing conifers increase acidity in the near-surface soil layers more than do hardwoods (Ovington, 1953; Alban, 1982) and, following replacement of some hardwoods by conifers, soil acidification has been reported (Miles, 1978). In a review of long-term European studies of soil acidification, the National Expert Group on Transboundary Air Pollution (NEGTAP, 2001) concluded that for recently planted stands (up to 60 years old), the main acidifying impact of trees was in the top 20 to $25 \mathrm{~cm}$ of the soil. Base cation uptake and accumulation in biomass and in the forest floor were identified as the main mechanisms, particularly in rapidly growing forests, although acid deposition also contributed. Below the rooting zone, acid deposition was the main cause of soil acidification.

Changes in forest management which encourage retention of base cations on site and increase inputs to the soil, particularly to the more acidic near-surface horizons, will be beneficial in ameliorating soil and stream water acidification. For example, introducing deeper rooted broadleaf tree species may encourage exploitation of base cation reserves deeper in the soil profile with subsequent 
re-cycling to the surface via litter fall and canopy leaching. Maintaining a rough forest canopy will also enhance base cation inputs from atmospheric deposition although beneficial effects may be offset by scavenging of acidic pollutants. This will depend partly on the future mix of base cations, sulphur pollutants and nitrogen compounds in the atmosphere as protocols to control emissions take effect. The overall effect of CCF on long-term acidification will depend on, the balance between base cation removal in forest products, the effects of maintaining a rough forest canopy on deposition inputs of acidifying pollutants and base cations, the choice of species and the overall effect on the nitrogen cycle.

It is important to recognise that the acid pollution climate of the UK is changing. The potential acidification of nitrogen deposition, now dominated by reduced nitrogen, currently exceeds that of sulphur deposition which has declined over the last 10-15 years (NEGTAP, 2001). The potential acidification to the UK, estimated in 1986 at $27 \mathrm{Gmol} \mathrm{yr}^{-1}$ from nitrogen deposition with a further $32 \mathrm{Gmol} \mathrm{yr}^{-1}$ from non-seasalt sulphur (total $60 \mathrm{Gmol} \mathrm{yr}^{-1}$ ) had, by 1997,

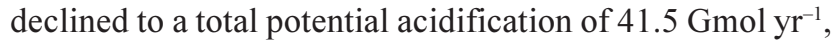
because the potential acidification from sulphur deposition had dropped to $14.5 \mathrm{Gmol} \mathrm{yr}^{-1}$, whilst the figure for nitrogen remained the same (NEGTAP, 2001). Thus, new forest management regimes will be implemented under a very different acid pollution climate from that when many of the studies of forestry and acidification were undertaken.

\section{Responses to atmospheric nitrogen deposition}

Over the last 10 to 15 years, the effects of atmospheric nitrogen deposition on forest ecosystems has been researched (Wright and Rasmussen, 1998; Carnol et al., 1997) with a particular emphasis in Europe and the UK on the response of coniferous forests. The concern is that nitrogen deposition inputs to forests in excess of biotic requirements ('nitrogen saturation') results in nitrate leaching to soil and surface waters accompanied, on acid sites, by hydrogen ions and aluminium. The response to increased atmospheric nitrogen inputs depends on the nitrogen status of the site, which is a key factor in determining its nitrogen retention capacity (Emmett et al., 1998). At nitrogen saturated sites (those where nitrogen inputs exceed biotic requirements), increasing nitrogen inputs result in large and rapid increases in nitrate leaching. At sites with a lower nitrogen status, the response to increased inputs is smaller and delayed. Site nitrogen status is determined by site characteristics, deposition and management history; one of the most useful indices combining these factors is the forest floor $\mathrm{C} / \mathrm{N}$ ratio (Gundersen et al., 1998). Above a C/N of 24, nitrate leaching is low and generally accounts for less than $10 \%$ of nitrate inputs. Below 24, nitrate leaching increases and represents a larger proportion of nitrate inputs until, at low ratios, nitrate outputs can exceed nitrate inputs indicating that nitrification is active and/or that the sinks for deposited and internally generated nitrate have been reduced (Emmett et al., 1998).

An important component of the 'nitrogen saturation' concept, which is particularly relevant to plantation forestry, is the interaction between forest age and nitrogen deposition. In a study of Welsh Sitka spruce plantations, Stevens et al. (1994) showed that soil water nitrate leaching fluxes exceeded nitrate inputs (estimated from the throughfall nitrate flux) at sites more than thirty years old (Fig. 2; Emmett et al., 1995). The onset of nitrate leaching was related to a decrease in biological sinks for nitrogen in combination with increased scavenging of nitrogen pollutants by the taller trees. Beyond the breakthrough point at which stands become net sources of nitrate (Fig. 2), nitrate leaching was highly variable and was linked to the fate of the incoming ammonium and soil type. In freely draining soils with organic horizons containing more than $1.7 \%-\mathrm{N}$, ammonium inputs stimulated nitrate production. Nitrate production did not increase in poorly drained soils where denitrification rates probably increased. Thus, two types of forest could be distinguished, those exhibiting no ability to retain incoming nitrate but retaining all incoming ammonium and those more nitrogen-rich sites which responded to increased ammonium inputs with immediate increases in nitrate production and nitrate leaching losses. Where nitrate leaching occurred in older stands, soil and stream waters were more acid and enriched with aluminium compared to

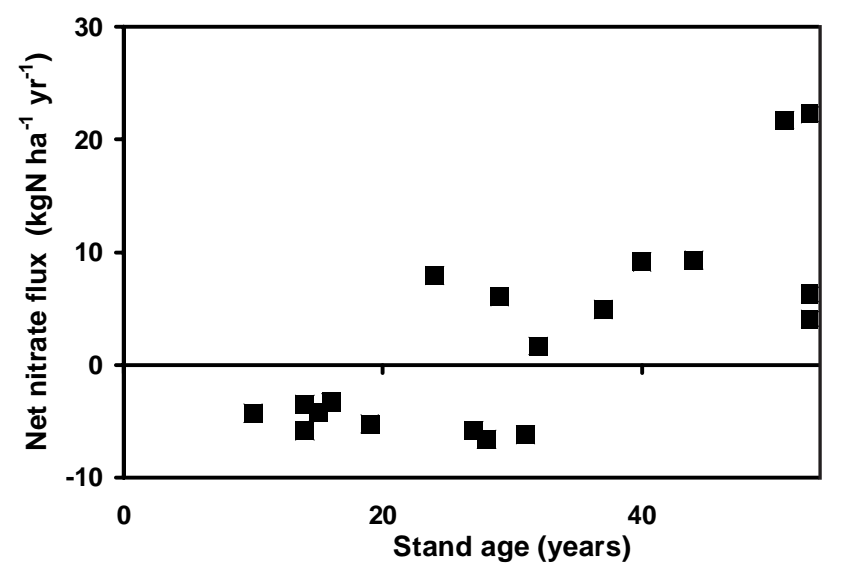

Fig. 2. The net soil water nitrate flux (outputs-inputs) below the rooting zone of 20 Sitka spruce plantations in Wales (Emmett et al., 1995) 


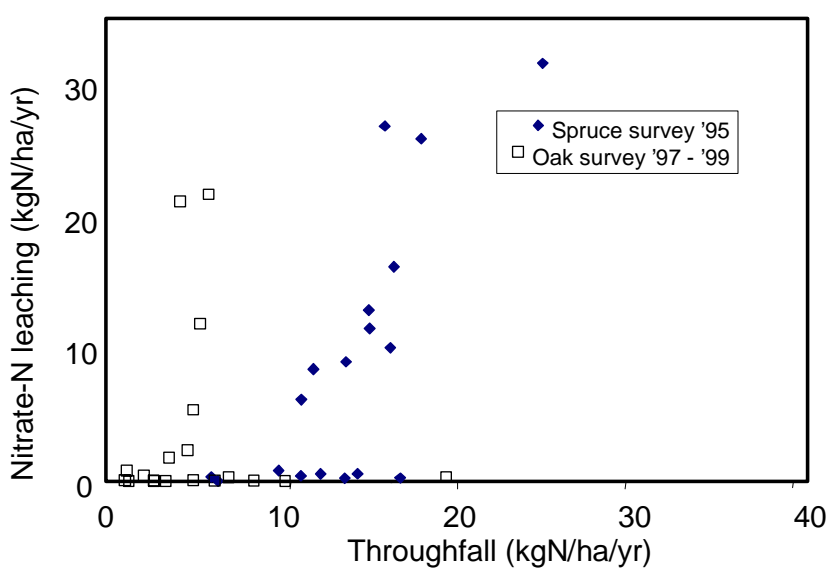

Fig. 3. Nitrate leaching losses beneath the rooting zone in relation to throughfall for 20 Sitka spruce plantations and 19 oak stands in Wales (Williams et al., 2000)

younger stands (Hughes et al., 1994).

The Welsh survey of Sitka spruce (Stevens et al., 1994) was followed by a study to determine whether broadleaved woodlands were more or less prone to nitrate leakage than conifers and to identify the factors controlling nitrate leaching (Williams et al., 2000). A survey of 19 oak stands throughout north-west and east Wales showed that the majority of oakwood stands had lower nitrate concentrations and fluxes relative to Sitka spruce on similar soils (Fig. 3) although four oak sites had leaching losses in excess of throughfall fluxes. This finding reflects results of earlier work at Gisburn forest where nitrate leaching losses were lowest beneath oak in comparison with Norway spruce, Scots pine and alder (Brown and Iles, 1991). At Llyn Brianne in mid-Wales, soil water was less acidic with much lower nitrate and aluminium concentrations beneath an oak stand compared to 28 year old Sitka spruce (Soulsby and Reynolds, 1992, 1994). However, because water fluxes were larger through the oak stand compared to the Sitka, part of this difference could be a dilution effect. In a comparative study between larch and Sitka spruce, Adamson et al. (1992) observed that concentrations of most ions were larger under Sitka than larch. In terms of fluxes, the only statistically significant differences were for nitrate and ammonium which were larger below the rooting zone of the Sitka spruce.

To explain the results of the Welsh oakwoods survey, more detailed studies were undertaken involving nitrogen addition experiments and experimental removal of understorey vegetation (Williams et al., 2000). The nitrogen addition experiments indicated higher nitrogen retention rates in the oak stands relative to the spruce. Stand characteristics and management were not good predictors of nitrate leaching in the oak stands. In particular, the presence of an active layer of ground vegetation was not important in reducing nitrate leaching in the long-term, although there may be short-term benefits in relation to felling. Soil nitrogen status and turnover, together with climatic variables such as rainfall and temperature, emerged as the important controls on nitrate leaching in oak stands.

In relation to a shift in forest management towards $\mathrm{CCF}$, guiding principles can be identified but specific recommendations are more problematic. Any change in the canopy structure which enhances the deposition of nitrogen may have long-term consequences through soil nitrogen enrichment and subsequent leaching and acidification. The extent to which this poses a problem will depend on factors such as site nitrogen deposition history, site management history, overall crop age and soil type. Importantly, there have been few direct comparisons of the relative effects on atmospheric deposition of conifer $v$. deciduous canopy (Weathers et al., 2000). Conifers may be more efficient scavengers of particles because they are evergreen and because the capture efficiency of needles is greater than leaves. This is generally supported by the available data (Weathers et al., 2000) with the suggestion of an enhancement factor for conifers compared to broadleaf of about 2 for wet plus dry sulphur deposition to low elevation stands in Europe (Ivens, 1990).

The effects of gross changes in canopy structure may be particularly important. It is recognised that deposition at the exposed edge of a forest where air can mix intimately with the foliage usually exceeds inputs to the areas of more uniform canopy (Environment Agency, 1998). For conifer forests in Scandinavia and the USA, edge to interior enhancement ratios of between 1.5 and 8 have been reported using a variety of measurement techniques including sodium deposition in throughfall and $\mathrm{Pb}$ content of the forest floor (Weathers et al., 2000). Similar effects might well be observed at any sharp discontinuity in woodland height such as where blocks of trees of different age adjoin each other (Environment Agency, 1998). A study of deposition to 3-5 $\mathrm{m}$ high spruce saplings in irregular shaped gaps (measuring about $15 \times 30 \mathrm{~m}$ ) within a high elevation spruce forest in the USA showed that sulphate fluxes in throughfall measured during the growing season beneath 20-30 $\mathrm{m}$ high mature trees at the gap edge were about three times those beneath the saplings (Lindberg and Owens, 1993). Throughfall fluxes of sulphate to the forest interior (93 $\mathrm{meq} \mathrm{m}^{-2}$ ) were about $15 \%$ lower than at the forest edge $\left(110 \mathrm{meq} \mathrm{m}^{-2}\right)$. Deposition to forests with an increasing mix of ages, species and gaps may therefore become much more spatially variable than for even aged plantations. The deposition of acidifying pollutants, base cations and metals are all likely to be affected depending on the dominant mode 
of deposition (dry, cloud droplet, particle, rain) so that the consequences for acidification are difficult to predict.

The interaction between nitrogen deposition and stand age must also be considered. If CCF were to result in fewer and smaller areas of mature Sitka spruce forest (i.e. greater than 30-40 years old), this would reduce nitrate leaching on well drained soils. Management options such as fertilisation with potassium and phosphorus can limit nitrate leaching in mature stands (Stevens et al., 1994), but this approach may not be considered sustainable and is unlikely to be adopted as part of CCF. The introduction of different species into existing Sitka spruce forest may well have beneficial effects with respect to nitrate leaching; oak woodland seems to have a greater capacity to retain nitrogen than Sitka spruce. However, the choice of species may be crucial. For example, introduction of alder, which fixes nitrogen symbiotically, could result in large nitrate leaching losses and acidification on acid sensitive sites (Brown and Iles, 1991). There is further evidence from studies on lowland woodland to show how broadleaf species differ in their nitrogen cycles. Kinniburgh and Trafford (1996) showed higher soil pore water nitrate concentrations under beech compared to ash at Blackwood near Winchester. This was attributed to differences in rooting patterns between the species although this hypothesis was not tested at the site.

\section{Conclusions}

It is difficult to predict the likely consequences for fresh water acidification of a change in the management of upland plantation conifer forestry to CCF. This arises because (i) of the uncertainty as to how CCF will be implemented in practice in upland spruce forests in the UK, (ii) the possible effects have to be inferred from studies originally designed for different purposes and (iii) the studies were undertaken in a pollution climate which differs from that which is likely over the next decade or so. However, principles can be identified which are applicable to CCF management on acidic and acid sensitive sites:

- Any move away from large scale patch clearfelling is likely to have benefits in terms of reduced nitrate leaching and reduced stream acidification at felling.

- Harvesting strategies which encourage retention of nitrate within the soil-plant system will also be beneficial.

- Changes in forest management which encourage retention of base cations within the soil-plant system and increase base cation inputs, either from external (atmospheric deposition) or internal (weathering) sources is likely to be beneficial in minimising long- term soil and stream water acidification associated with soil base cation depletion.

- Introduction of deeper rooting trees may encourage exploitation of base cation reserves deeper in the soil profile and re-cycle them to the more acidic surface horizons via litter fall and canopy leaching.

- Any change in the canopy structure which enhances the atmospheric deposition of nitrogen and sulphur compounds may have undesirable consequences in the long-term through soil acidification and nitrogen enrichment.

- If CCF results in a smaller proportion of mature Sitka spruce forest (i.e. greater than 30-40 years old), this will reduce nitrate leaching on well drained acid soils.

- Introduction of species which develop an ecosystem with greater potential to retain nitrogen deposited from the atmosphere should be beneficial on acid sensitive sites.

Most of these conclusions are inferred from studies undertaken over the last twenty years, at a time when upland forest policy was concerned mainly with timber growth and production from even-aged plantations dominated by Sitka spruce. Given the uncertainties in the science and the somewhat chequered history of relationships between the forest and water industries in the UK, changes in forest management to CCF must be accompanied by an adequate and well designed programme of research from the earliest planning stages of CCF trials to ensure that the environmental effects are assessed in a scientifically rigorous and robust manner.

\section{Acknowledgements}

The National Assembly for Wales funded this work as part of the Scoping Study for Acid Waters in Wales Strategy. The author would like to thank members of the project board, especially Havard Prosser (National Assembly for Wales) and Wendy Merrett (Environment Agency Wales) for their helpful comments on earlier drafts. The comments from two anonymous referees were also much appreciated.

\section{References}

Adamson, J.K., Hornung, M., Kennedy, V.H., Norris, D.A., Paterson, I.S. and Stevens, P.A., 1992. Soil Solution Chemistry Under Adjacent Stands of Japanese Larch and Sitka Spruce at Three Contrasting Locations in Britain. Report to the Department of the Environment DoE/NERC contract PECD 7/ 12/049, Institute of Terrestrial Ecology, Merlewood Research Station, Cumbria, UK. 38pp.

Alban, D.H., 1982. Effects of nutrient accumulation by aspen, 
spruce and pine on soil properties. Soil Sci. Soc. Amer. J., 46, 153-457.

Anderson, M.L., 1960. Norway spruce - silver fir - beech mixed selection forest. Is it possible to reproduce this in Scotland? Scottish Forestry, 14, 87-93.

Brown, A.H.F. and Iles, M.A., 1991. Water chemistry profiles under four tree species at Gisburn, NW England. Forestry, 64, 169-187.

Carnol, M., Ineson, P., Anderson, J.M., Beese, F., Berg, M.P., Bolger, T., Couteaux, M.M., Cudlin, P., Dolan, S., Raubuch, M. and Verhoef, H.A., 1997. The effects of ammonium sulphate deposition and root sinks on soil solution chemistry in coniferous forest soils. Biogeochemistry, 38, 255-280.

Emmett, B.A., Stevens, P.A. and Reynolds, B., 1995. Factors influencing nitrogen saturation in Sitka spruce stands in Wales, UK. Water Air Soil Pollut., 85, 1629-1634.

Emmett, B.A., Boxman, D., Bredemeier, M., Gundersen, P., Kjönaas, O.J., Moldan, F., Schleppi, P., Tietema, A. and Wright, R.F., 1998. Predicting the effects of atmospheric nitrogen deposition in conifer stands: Evidence from the NITREX ecosystem-scale experiments. Ecosystems, 1, 352-360.

Environment Agency, 1998. Broadleaf Woodlands: The Implications for Water Quantity and Quality. R\&D Publication No. 5, Stationery Office, London, UK. 37pp.

Evans, C., Jenkins, A., Helliwell, R., Ferrier, R. and Collins, R., 2001. Freshwater Acidification and Recovery in the United Kingdom. Centre for Ecology and Hydrology, Wallingford, UK. 80pp.

Fahey, T.J., Hill, M.O., Stevens, P.A., Hornung, M. and Rowland, A.P., 1991. Nutrient accumulation in vegetation following conventional and whole-tree harvest of Sitka spruce plantations in north Wales. Forestry, 64, 271-288.

Forestry Commission, 1993. Forests and Water Guidelines. Third Edition, HMSO, London, UK. 32pp.

Forestry Commission, 1998. The UK Forestry Standard. Forestry Commission, Edinburgh, UK. 74pp.

Forestry Commission, 2003. Forests and Water Guidelines. Fourth Edition, HMSO, London, UK. 66pp.

Forestry Commission / Environment Agency, 2001. Outputs from Harvesting R\&D Projects and Recommendations for Forests and Water Guidelines Review. Forestry Commission and Environment Agency Joint R\&D Outputs Working Group, October 2001. 34pp.

Gundersen, P., Callesen, I. and de Vries, W., 1998. Nitrate leaching in forest ecosystems is related to forest floor $\mathrm{C} / \mathrm{N}$ ratios. Environ. Pollut., 102, 403-407.

Hornung, M., 1985. Acidification by trees and forests. Soil Use Manage., 1, 24-28.

Hughes, S., Norris, D.A., Stevens, P.A., Reynolds, B. and Williams, T.G., 1994. Effects of forest age on surface drainage water and soil solution aluminium chemistry in stagnopodzols in Wales. Water, Air Soil Pollut., 77, 115-139.

Ivens, W.P.M.F., 1990. Atmospheric deposition onto forests: An analysis of the deposition variability by means of throughfall measurements. Nederlande Geografische Studies, 118. Amsterdam, The Netherlands.

Kinniburgh, D.G. and Trafford, J.M., 1996. Unsaturated zone pore water chemistry and the edge effect in a beech forest in Southern England. Water Air Soil Pollut, 2, 421-450.

Lindberg, S.E. and Owens, J.G., 1993. Throughfall studies of deposition to forest edges and gaps in montane ecosystems. Biogeochemistry, 19, 173-194.

Mason, W. and Kerr, G., 2001. Transforming Even-aged Conifer Stands to Continuous Cover Management. Information Note 40, Forestry Commission, Edinburgh, UK. 8pp.
Mason, W., Kerr, G. and Simpson, J., 1999. What is Continuous Cover Forestry? Information Note 29, Forestry Commission, Edinburgh, UK. 8pp.

Miles, J., 1978. The Influence of Trees on Soil Properties. Annual Report of the Institute of Terrestrial Ecology 1977, Institute of Terrestrial Ecology, Huntingdon, UK. 7-11.

National Assembly for Wales, 2000. Woodlands for Wales. The National Assembly for Wales Strategy for Trees and Woodlands. National Assembly for Wales, Cardiff, UK. 49pp.

Neal, C. and Reynolds, B., 1998. The Impact of Conifer Harvesting and Replanting on Upland Water Quality. R\&D Technical Report P211, Environment Agency, Bristol, UK. 137pp.

Neal, C., Reynolds, B., Wilkinson, J., Hill, T., Neal, M., Hill, S. and Harrow, M., 1998a. The impacts of conifer harvesting on runoff water quality: a regional survey for Wales. Hydrol. Earth Syst. Sci., 2, 323-344.

Neal, C., Reynolds, B., Adamson, J.K., Stevens, P.A., Neal, M. and Harrow, M., 1998b. Analysis of the impacts of major anion variations on surface water acidity particularly with regard to conifer harvesting: case studies from Wales and Northern England. Hydrol. Earth Syst. Sci., 2, 303-322.

Neal, C., Reynolds, B., Neal, M., Wickham, H., Hill, L. and Williams, B., 2004, The impact of conifer harvesting on stream water quality: the Afon Hafren, mid-Wales. Hydrol. Earth Syst. Sci., 8, 503-520.

NEGTAP, 2001. Transboundary Air Pollution: Acidification, Eutrophication and Ground-Level Ozone in the UK. Report Prepared by the National Expert Group on Transboundary Air Pollution, Department for Environment, Food and Rural Affairs, London, UK. 314pp.

Nisbet, T., Dutch, J. and Moffat, A., 1997. Whole-Tree Harvesting. A Guide to Good Practice. Forestry Commission Practice Guide, Forestry Commission, Edinburgh, UK. 12pp.

Ovington, J.D., 1953. Studies of the development of woodland conditions under different trees. I. Soil pH. J. Ecol., 41, 13-34.

Reynolds, B. and Stevens, P.A., 1998. Assessing soil calcium depletion following growth and harvesting of Sitka spruce plantation forestry in the acid sensitive Welsh uplands. Hydrol. Earth Syst. Sci., 2, 345-352.

Soulsby, C. and Reynolds, B., 1992. Modelling hydrological processes and aluminium leaching in an acid soil at Llyn Brianne, Mid-Wales. J. Hydrol., 138, 409-429.

Soulsby, C. and Reynolds, B., 1994. The chemistry of throughfall, stemflow and soil water beneath oak woodland and moorland vegetation in upland Wales. Chem. Ecol., 9, 115-134.

Stevens, P.A. and Hornung, M., 1988. Nitrate leaching from a felled Sitka spruce plantation in Beddgelert forest, north Wales. Soil Use Manage., 4, 3-9.

Stevens, P.A. and Hornung, M., 1990. Effect of harvest intensity and ground flora re-establishment on inorganic-N leaching from a Sitka spruce plantation in north Wales, UK. Biogeochemistry, 10, 53-65.

Stevens, P.A. and Reynolds, B., 1993. A Review of the Water Quality Implications of Conifer Harvesting in the UK. 1 . Literature Review and Recommendations for Research. R\&D Note 156, Environment Agency, Bristol, UK. 57pp.

Stevens, P.A., Norris, D.A., Sparks, T.H. and Hodgson, A.L., 1994. The impacts of atmospheric $\mathrm{N}$ inputs on throughfall, soil and stream water interactions for different aged forest and moorland catchments in Wales. Water Air Soil Pollut., 73, 297-317.

Stevens, P.A., Reynolds, B. and Neal, C., 2001. Trends in stream chemistry in upland catchments in Wales and effects of forest management, In: Detecting Environmental Change: Science and Society. 17-20 July 2001, Abstracts of papers, London, UK, Centre for Ecology and Hydrology, Merlewood, 161-162. 
Timmis, T., 1994. Bradford Plan Continuous Cover Forestry: Development, History and Status Quo. Quart. J. Forestry, 88, 188 .

Weathers, K.C., Lovett, G.M., Likens, G.E. and Lathrop, R., 2000. The effect of landscape features on deposition to Hunter Mountain, Catskill Mountains, New York. Ecol. Appl., 10, 528540 .
Williams, D.L., Emmett, B.A., Brittain, S.A., Pugh, B., Hughes, S., Norris, D., Meadows, K., Richardson, C. and Bell, S., 2000. Influence of Forest Type, Structure and Management on Nitrate Leaching. Report to National Power / Powergen / Eastern Power Joint Environmental Programme, Institute of Terrestrial Ecology, Bangor, UK. 56pp.

Wright, R.F. and Rasmussen, L., (Eds.) 1998. The Whole Ecosystem Experiments of the NITREX and EXMAN Projects. Forest Ecol. Manage., 101, 1-363. 